WORLD PSYCHIATRIC ASSOCIATION - 19th WPA World Congress of Psychiatry

Lisbon, Portugal , 21 - 24 August 2019

\title{
Multi-family Psychoeducation Groups (McFarlane's Model) In The Treatment Of Schizophrenia - Development And Pilot Test Of The Portuguese Version
}

Maria Luisa Brito, PhD, MSc, RN. Escola Superior de Enfermagem de Coimbra, Portugal Ibrito@esenfc.pt

\section{Abstract Number: WCP19-0472}

Objectives: To develop and pilot-test a Portuguese version of the Multi-Family Psychoeducation Groups (McFarlane's model); to explore its efficacy in the treatment of schizophrenia in a Portuguese context.

Background and aims: Family interventions are considered an important component of the integrated treatment of schizophrenia, and McFarlane's Multi-Family Psychoeducation Groups have shown particularly good results.

Aims: to provide an evidence-based and culturally tested intervention; to contribute for its implementation in Portugal.

Materials and methods: Schizophrenia patients attending a Portuguese public service were randomly assigned to multi-family group (6 patients/ 12 caregivers) and control group (8 patients/ 9 caregivers). Information workshops and 'Guidelines for families' were prepared, following translation and cultural adaptation of McFarlane's original materials
The intervention (38 group sessions over 3 years) was delivered as an adjunct to standard services (regular appointments with a doctor). Quantitative outcomes were measured after 2 years, including: re-hospitalizations, symptoms, functioning, patients and family members' perceived quality of life and ability to manage illness. Participants' written opinions about each session were content analyzed.

Results: The small sample size precluded statistical differences between groups. However, patients and their caregivers reported their satisfaction with the intervention: increased knowledge about the illness; sharing experiences and feelings with other people; patients' improved therapeutic compliance; better communication within the family; increased vocational attempts and outcomes.

Conclusions: Multi-Family Psychoeducation Groups are definitely useful in meeting the needs for information and support of schizophrenia patients and their families. Research should focus on how to implement them as standard care in Portugal.

\section{References:}

Brito, L. (2006) - Intervenções psicoeducativas para famílias de pessoas com esquizofrenia - uma revisão da literatura. Revista Portuguesa de Enfermagem. 5(Março), 15-24.

Grácio, J., Gonçalves-Pereira, M., \& Leff, J. (2018). Key Elements of a Family Intervention for Schizophrenia: A Qualitative Analysis of an RCT. Family Process, 57(1), 100-112. https://doi.org/10.1111/famp.12271

Harvey, C. (2018). Family psychoeducation for people living with schizophrenia and their families. BJPsych Advances, 24(1), 9-19. doi:10.1192/bja.2017.4

Jewell, T. C., Downing, D., \& McFarlane, W. R. (2009). Partnering with families: Multiple family group psychoeducation for schizophrenia. Journal of Clinical Psychology, 65(8), 868-878. https://doi.org/10.1002/jclp.20610

Kealey, E. M., Leckman-Westin, E., Jewell, T. C., \& Finnerty, M. T. (2015). Multifamily Group Psychoeducation in New York State: Implementation and Fidelity Outcomes. Psychiatric Services, 66(11), 1194-1199. https://doi.org/10.1176/appi.ps.201400403

McFarlane, W. R. (2016). Family Interventions for Schizophrenia and the Psychoses: A Review. Family Process55(3), 460482. doi:10.1111/famp.12235

Öksüz, E., Karaca, S., Özaltın, G., \& Ateş, M. A. (2017). The Effects of Psychoeducation on the Expressed Emotion and Family Functioning of the Family Members in First-Episode Schizophrenia. Community Mental Health Journal, 53(4), 464473. https://doi.org/10.1007/s10597-017-0086-y

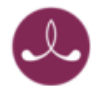

